\title{
Bacteroides xylanisolvens sp. nov., a xylan- degrading bacterium isolated from human faeces
}

\author{
Correspondence \\ Annick Bernalier-Donadille \\ bernal@clermont.inra.fr
}

\author{
Christophe Chassard, ${ }^{1}$ Eve Delmas, ${ }^{1}$ Paul A. Lawson ${ }^{2}$ \\ and Annick Bernalier-Donadille ${ }^{1}$ \\ ${ }^{1}$ Unité de Microbiologie, INRA, Centre de Recherches de Clermont Ferrand - Theix, \\ 63122 Saint Genès-Champanelle, France
}

${ }^{2}$ Department of Botany and Microbiology, University of Oklahoma, Norman, OK 73019, USA
Plant fibres constitute one of the main sources of polysaccharides in the human colon that are degraded extensively by the endogenous microbial community. Plant cell-wall polysaccharides, which mainly include celluloses and hemicelluloses (xylan, arabinoxylan, etc.), represent about $30 \%$ of the total dietary fibre ingested by humans daily. Xylan is the most abundant of these cell-wall polysaccharides. Despite the extensive degradation of xylan in the colon (Slavin et al., 1981), the diversity of the predominant bacteria involved in xylan breakdown has not been explored extensively (but see Bayliss \& Houston, 1984; Wedekind et al., 1988; Chassard et al., 2007). Bacteroides species, which constitute a predominant bacterial group of the human gut microbiota, play key roles in the degradation and fermentation of organic matter present in the colon (Salyers, 1995). Some Bacteroides species have been shown to be able to obtain carbon and energy via hydrolysis of soluble or wellhydrated polysaccharides (Salyers, 1995; Robert et al., 2007; Chassard et al., 2007). Significant xylanolytic activity has

The GenBank/EMBL/DDBJ accession number for the 16S rRNA gene sequence of strain $X B 1 A^{\top}$ is $A M 230650$. been found in some Bacteroides species isolated from the human gut, in particular in Bacteroides ovatus and Bacteroides fragilis subspecies A (Salyers et al., 1977; Hespell \& Whitehead, 1990). The xylanase system of $B$. ovatus was subsequently explored in detail by Weaver $e t$ al. (1992). During an investigation of the xylan-degrading microbial community from the human colon (Chassard et al., 2007), we isolated the xylanolytic strains reported herein.

Six bacterial strains $\left(\mathrm{XB1} \mathrm{A}^{\mathrm{T}}, \mathrm{XB} 4 \mathrm{~A}, \mathrm{XB} 3 \mathrm{~A}, \mathrm{XB} 2 \mathrm{~A} 2, \mathrm{XB} 41 \mathrm{~A}\right.$ and $\mathrm{XO} 85 \mathrm{C} 13$ ) were isolated from the faeces of three healthy French adults (strains XB1A ${ }^{\mathrm{T}}, \mathrm{XB} 4 \mathrm{~A}$ and XO85C13 were from a 31-year-old male, strain XB41A was from a 40year-old female and strains XB3A and XB2A2 were from a 43-year-old female). All liquid and solid media were prepared, dispensed and inoculated by using strictly anaerobic techniques (Hungate, 1969), with $100 \% \mathrm{O}_{2}$-free $\mathrm{CO}_{2}$ gas. Freshly voided faeces $(1 \mathrm{~g})$ were transferred into $10 \mathrm{ml}$ sterile anoxic mineral solution. Serial 10-fold dilutions down to $10^{-11}$ of this faecal suspension were then carried out in mineral solution. These faecal dilutions were inoculated $(0.3 \mathrm{ml})$ into liquid basal xylanolytic (BX) medium (10 ml per tube) with commercial (Sigma) oat 
spelts or birchwood xylan as the sole energy source (Chassard et al., 2007). After 15 days incubation at $37^{\circ} \mathrm{C}$, the presence of xylanolytic organisms in faecal dilution cultures was estimated by measuring xylanase activity. Detection of xylanase activity was performed by using an agar plate method as described by Forano et al. (1994) and Chassard et al. (2007). Xylanolytic bacteria were then isolated from the highest-dilution faecal cultures showing xylanase activity $\left(10^{-8}-10^{-9}\right)$. The medium used for isolation of xylanolytic strains was solid BX medium containing oat-spelt xylan as energy source. All strains were isolated by using the roll-tube technique. After three to five successive subcultures on roll-tubes and BX medium broth, isolates were examined for purity by phase-contrast microscopy, from cultures grown with oat-spelt xylan and xylose (both at $2 \mathrm{~g} \mathrm{l}^{-1}$ ). The medium used for further routine cultivation of the xylanolytic isolates was BX medium with oat-spelt xylan as substrate.

DNA extraction, PCR and sequencing of the 16S rRNA gene of the novel strains were performed as described by Robert et al. (2007). Xylanolytic strains were grown for $24 \mathrm{~h}$ in $50 \mathrm{ml}$ semi-synthetic BC medium (Robert \& Bernalier-Donadille, 2007) with glucose $\left(2 \mathrm{gl}^{-1}\right)$ as carbon source. Cells were harvested by centrifugation for $15 \mathrm{~min}$ at $9000 \mathrm{~g}$ at $4{ }^{\circ} \mathrm{C}$. The bacterial pellet was then subjected to DNA extraction (Easy DNA kit genomic DNA isolation; Invitrogen). 16S rRNA genes of the strains investigated were then amplified by using the universal primers F8 (5' AGAGTTTGATCMTGGCTC-3') and 1492R (5'-GNTACCTTGTTACGACTT-3'). PCR products were purified by using the Strataprep PCR purification kit (OZYME) and were sequenced by use of a Big Dye Terminator Cycle Sequencing kit and ABI PRISM 310 automated sequencer (Applied Biosystems) according to the manufacturer's specifications, yielding continual stretches of $>1400$ bases. The closest known relatives of the new isolates were determined by performing database searches with the program FASTA (Pearson \& Lipman, 1985). These reference sequences and those of other related strains were retrieved from GenBank and aligned with the newly determined sequences by using the program SEQtools (Rasmussen, 2002). The resulting multiple-sequence alignment was corrected manually by using the program GeneDoc (Nicholas et al., 1997) and a phylogenetic tree was constructed according to the neighbour-joining method (Saitou \& Nei, 1987) with the programs SEQtools and TreeView (Page, 1996). The G $+\mathrm{C}$ content of the genomic DNA was determined by HPLC by the Deutsche Sammlung von Mikroorganismen und Zellkulturen GmbH (DSMZ, Braunschweig, Germany).

The six new isolates were found to be genetically highly related to each other, displaying levels of $16 \mathrm{~S}$ rRNA gene sequence similarity of between 99 and $100 \%$. Treeing analysis revealed that the new isolates were members of the Bacteroides-Prevotella-Porphyromonas rRNA supercluster of organisms (data not shown), and demonstrated a specific affinity with members of the genus Bacteroides
(Chassard et al., 2007). The phylogenetic position of strain $\mathrm{XB1A}^{\mathrm{T}}$, by using a reduced dataset, is shown in Fig. 1. Analysis showed that this strain clustered with B. ovatus NCTC $11153^{\mathrm{T}}$ (97.5\% 16S rRNA sequence similarity), $B$. finegoldii JCM $13345^{\mathrm{T}}(96.6 \%)$ and B. thetaiotaomicron ATCC $29148^{\mathrm{T}}(95.6 \%)$. There is no precise correlation between the level of 16S rRNA gene sequence divergence and species delineation, but it is generally recognized that similarity values of $\leqslant 97 \%$ are significant (Stackebrandt \& Goebel, 1994). However, Stackebrandt \& Ebers (2006) have made the recommendation that this value can be increased to $98.7-99 \%$ without sacrificing the quality and precision of a 'species' description, and as an aid to taxonomists. To determine the genotypic relatedness of strain $\mathrm{XB}^{\mathrm{T}} \mathrm{A}^{\mathrm{T}}$, DNA-DNA hybridization experiments between this xylanolytic isolate and the type strain of its closest relative, $B$. ovatus, was performed by the DSMZ Identification Service. DNA from strain $\mathrm{XB1A}^{\mathrm{T}}$ and B. ovatus DSM $1896^{\mathrm{T}}$ was isolated by using a French pressure cell from cells harvested from BHI broth medium and was further purified by chromatography on hydroxyapatite (Cashion et al., 1977). DNA-DNA hybridization experiments were carried out as described by De Ley et al. (1970) as modified by Huß et al. (1983) by using a model Cary 100 Bio UV/Vis spectrophotometer equipped with a Peltier-thermostatted $6 \times 6$ multicell changer and a temperature controller with in situ temperature probe. Strain $\mathrm{XB}^{\mathrm{T}} \mathrm{A}^{\mathrm{T}}$ showed a level of DNADNA relatedness of $41.9 \%$ with its closest neighbour, $B$. ovatus DSM $1896^{\mathrm{T}}$. This low level of DNA-DNA relatedness $(<70 \%)$ with the most closely related Bacteroides species indicated that strain $\mathrm{XB} 1 \mathrm{~A}^{\mathrm{T}}$ represented a novel species. The $\mathrm{G}+\mathrm{C}$ content of strain $\mathrm{XB1A}^{\mathrm{T}}$ was $42.8 \mathrm{~mol} \%$, compared with values of $40-42,42-43$ and $42.4-43.0 \mathrm{~mol} \%$ for B. ovatus, B. thetaiotaomicron and B. finegoldii, respectively (Table 1 ). The DNA G $+\mathrm{C}$ content of strain $\mathrm{XB1A}^{\mathrm{T}}$ thus supported its affiliation with members of the genus Bacteroides, which have a DNA $\mathrm{G}+\mathrm{C}$ content of $40-48 \mathrm{~mol} \%$ (Shah, 1992).

Cell morphology and motility were studied in $18 \mathrm{~h}$ xylosegrown cultures by phase-contrast microscopy and by electron microscopy after negative staining of whole cells with $2 \%$ uranyl acetate. The Gram reaction was determined by using the conventional Gram stain. Cell morphology and cell-wall structure were further observed on ultrathin sections by transmission electron microscopy (Philips 400) after staining with uranyl acetate and lead citrate (Bernalier et al., 1996). The presence of catalase and cytochrome oxidase was examined by standard methods. The optimal growth temperature of strain $\mathrm{XB1A}^{\mathrm{T}}$ was determined in semi-synthetic BC medium (Robert \& Bernalier-Donadille, 2007) containing xylose $\left(2 \mathrm{~g} \mathrm{l}^{-1}\right)$, at $\mathrm{pH} 6.8$, over the temperature range $25-45{ }^{\circ} \mathrm{C}$ (at $1{ }^{\circ} \mathrm{C}$ intervals). The influence of $\mathrm{pH}$ on growth of strain $\mathrm{XB}^{\mathrm{A}} \mathrm{A}^{\mathrm{T}}$ was evaluated in semi-synthetic BC medium containing xylose $\left(2 \mathrm{~g} \mathrm{l}^{-1}\right)$ at $37^{\circ} \mathrm{C}$. The $\mathrm{pH}$ range studied was 5.5-7.5 (at $0.1 \mathrm{pH}$ unit intervals, adjusted with varying concentrations of $\mathrm{NaHCO}_{3}$ in the medium). 


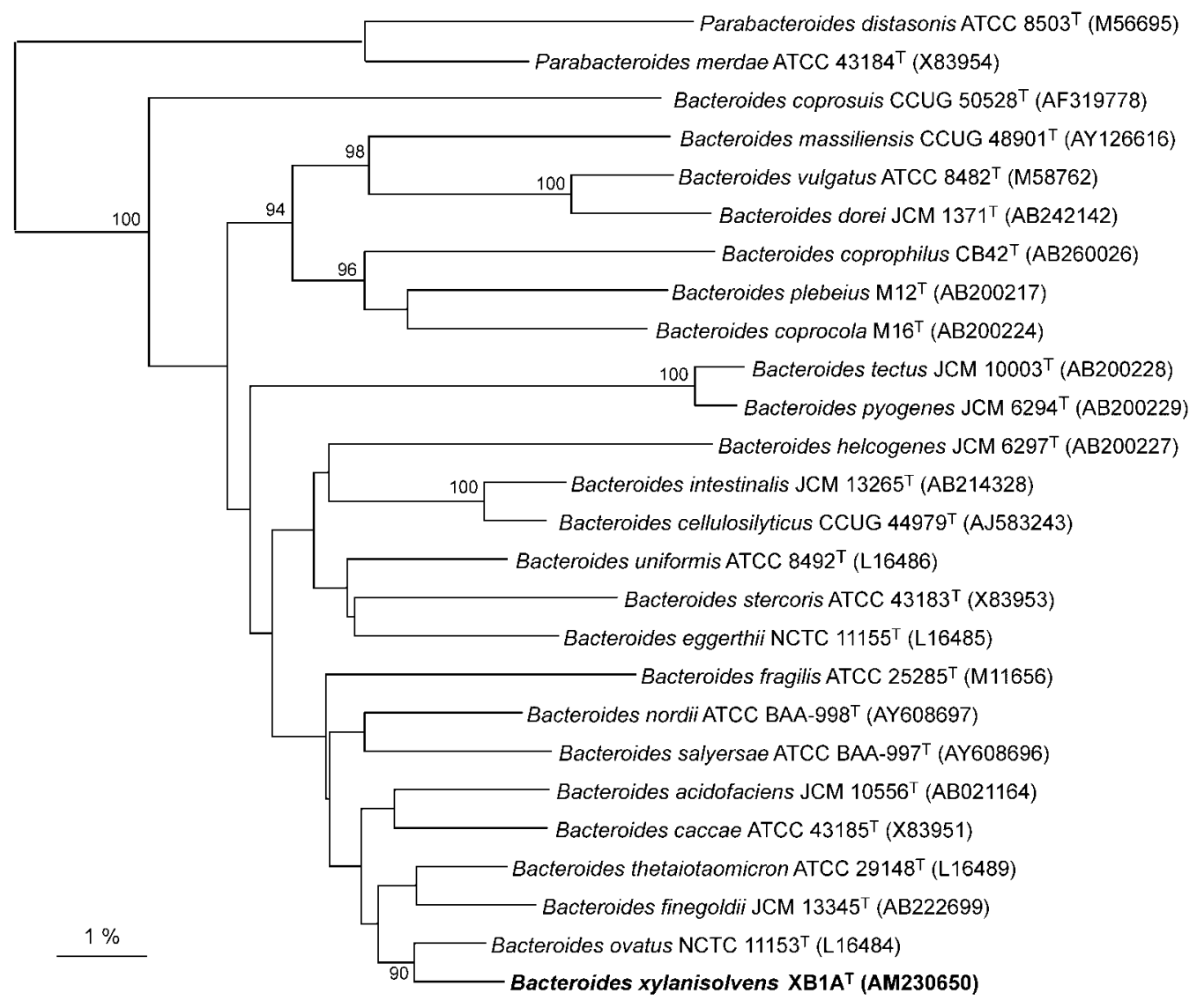

Fig. 1. Neighbour-joining tree based on $16 \mathrm{~S}$ rRNA gene sequences showing the phylogenetic relationship between strain $\mathrm{XB1} \mathrm{A}^{\top}$ and some related members of the genus Bacteroides. The tree was based on a comparison of approximately $1350 \mathrm{nt}$. Bootstrap values, expressed as percentages of 500 replications, are given at branch points (only values $\geqslant 90 \%$ are shown). Bar, $1 \%$ sequence divergence.

Cells of strain $\mathrm{XB} 1 \mathrm{~A}^{\mathrm{T}}$ were rods with rounded ends, with a mean length of $1.8-2.5 \mu \mathrm{m}$ and mean width of $0.2-0.3 \mu \mathrm{m}$. Cells occurred singly or in pairs. Cells stained Gramnegative and thin sections examined by transmission electron microscopy showed a Gram-negative cell-wall structure. Negatively stained cells revealed the absence of flagella. Viable cells could not be recovered from cultures held at $100{ }^{\circ} \mathrm{C}$ for $10 \mathrm{~min}$ and no spores were observed in xylan- or in xylose-grown cultures incubated at $37^{\circ} \mathrm{C}$ for almost 1 month. Strain $\mathrm{XB1A}^{\mathrm{T}}$ was strictly anaerobic and required an $\mathrm{O}_{2}$-free medium at a redox potential sufficient to decolorize resazurin $\left(E_{0}^{\prime}=-50 \mathrm{mV}\right)$. Strain $\mathrm{XB1A}^{\mathrm{T}}$ was catalase- and cytochrome oxidase-negative, unlike $B$. ovatus and $B$. thetaiotaomicron, which are catalase-positive (Moore \& Holdeman, 1974). With xylose as substrate, the optimal growth temperature was $38^{\circ} \mathrm{C}$, with growth occurring from 25 to $42{ }^{\circ} \mathrm{C}$. Strain $\mathrm{XB1A}^{\mathrm{T}}$ grew from an initial $\mathrm{pH}$ of 6.0 up to 7.2, with optimal growth at $\mathrm{pH} 6.8$. These optimal growth conditions are in line with those found in the human colon. Rumen fluid was not required for growth.
The results of further phenotypic analyses are given in the species description. Other physiological, biochemical and enzyme activity tests were performed by using API $20 \mathrm{~A}$ and API Rapid ID 32A kits (bioMérieux), according to the manufacturer's instructions, with incubation at $37{ }^{\circ} \mathrm{C}$ in an anaerobic chamber. Results of chemotaxonomic analyses of strain $\mathrm{XB} 1 \mathrm{~A}^{\mathrm{T}}$ and B. ovatus JCM $5824^{\mathrm{T}}$, B. thetaiotaomicron JCM $5827^{\mathrm{T}}$ and B. finegoldii DSM $17565^{\mathrm{T}}$ are summarized in Table 1. Strain XB1A ${ }^{\mathrm{T}}$ could be differentiated from $B$. ovatus JCM $5824^{\mathrm{T}}$ by its ability to use mannitol, melezitose and sorbitol and to produce acid from glycerol. Furthermore, strain $\mathrm{XB1A}^{\mathrm{T}}$ expressed glutamyl glutamic acid arylamidase activity, in contrast to the results for $B$. ovatus, and $B$. ovatus expressed leucine arylamidase activity, whereas strain $\mathrm{XB} 1 \mathrm{~A}^{\mathrm{T}}$ did not. Several characteristics allowed us to differentiate strain $\mathrm{XB}^{\mathrm{T}} \mathrm{A}^{\mathrm{T}}$ from $B$. thetaiotaomicron DSM $5827^{\mathrm{T}}$ and B. finegoldii DSM $17565^{\mathrm{T}}$ (Table 1). In particular, B. thetaiotaomicron showed a large number of positive results in tests for enzyme activities, in contrast to the results for strain $\mathrm{XB}^{\mathrm{T}} \mathrm{A}^{\mathrm{T}}$ and $B$. finegoldii. Strain $\mathrm{XB}^{\mathrm{T}} \mathrm{A}^{\mathrm{T}}$ was able to utilize trehalose, D-mannitol, 
Table 1. Differential characteristics between strain $X B 1 A^{\top}$ and related species of the genus Bacteroides

Strains: 1 , XB1A ${ }^{\mathrm{T}} ; 2$, B. ovatus JCM $5824^{\mathrm{T}}$; 3, B. thetaiotaomicron JCM $5827^{\mathrm{T}}$; 4, B. finegoldii JCM $13345^{\mathrm{T}}$. Data for reference strains are from Bakir et al. (2006) except where indicated. +, Positive; -, negative; ND, no data available.

\begin{tabular}{|lcccc|}
\hline Characteristic & $\mathbf{1}$ & $\mathbf{2}$ & $\mathbf{3}$ & $\mathbf{4}$ \\
\hline Starch utilization & - & $+^{*}$ & $+^{*}$ & $\mathrm{ND}$ \\
Acid produced from: & & & & \\
$\quad$ Salicin & + & + & - & + \\
Trehalose & + & + & + & - \\
D-Mannitol & + & - & - & - \\
Glycerol & + & - & - & - \\
Melezitose & + & - & - & - \\
D-Sorbitol & + & - & - & - \\
Enzyme activities & & & & \\
Arginine arylamidase & - & - & + & - \\
Phenylalanine arylamidase & - & - & + & - \\
Leucine arylamidase & - & + & + & - \\
Tyrosine arylamidase & - & - & + & - \\
Glycine arylamidase & - & - & + & - \\
Histidine arylamidase & - & - & + & - \\
Glutamyl glutamic acid arylamidase & + & - & + & - \\
Serine arylamidase & - & - & + & - \\
DNA G + C content (mol\%) & 42.8 & 42 & 43 & 42.4 \\
\hline
\end{tabular}

${ }^{\star}$ Data from Salyers et al. (1977).

glycerol, melezitose and D-sorbitol, whereas B. finegoldii is unable to ferment these substrates (Bakir et al., 2006).

The cellular fatty acid composition of strain $\mathrm{XB1A}^{\mathrm{T}}$ was determined by HPLC at the DSMZ. The major cellular fatty acid was anteiso- $\mathrm{C}_{15: 0}(33.8 \%)$, in agreement with data for the genus Bacteroides as described by Miyagawa et al. (1979). Other cellular fatty acids found in strain XB1A ${ }^{\mathrm{T}}$ included iso- $\mathrm{C}_{17: 0} 3-\mathrm{OH}(23.5 \%)$ and iso- $\mathrm{C}_{15: 0}(10.3 \%)$. B. ovatus JCM $5824^{\mathrm{T}}$, B. thetaiotaomicron JCM $5827^{\mathrm{T}}$ and B. finegoldii DSM $17565^{\mathrm{T}}$ also contain anteiso- $\mathrm{C}_{15: 0}$, iso$\mathrm{C}_{15: 0}$ and iso- $\mathrm{C}_{17: 0} 3-\mathrm{OH}$ as major cellular fatty acids, but the proportions of iso- $\mathrm{C}_{15: 0}$ and iso- $\mathrm{C}_{17: 0} 3-\mathrm{OH}$ were lower in these species than in strain XB1A ${ }^{\mathrm{T}}$ (7-9 and $12-$ $16 \%$, respectively).

Degradation and fermentation of different polysaccharides, such as xylan, starch or cellulose found in dietary fibres, by strain $\mathrm{XB}_{1 \mathrm{~A}}^{\mathrm{T}}$ were studied in $\mathrm{BX}$ broth medium $(10 \mathrm{ml}$ per tube) containing $100 \mathrm{mg}$ polysaccharide as sole energy source. Cultures were incubated at $37{ }^{\circ} \mathrm{C}$ for $2-4$ days. After incubation, substrate utilization was estimated by measuring bacterial growth [optical density of the cultures at $600 \mathrm{~nm}$ or determination of bacterial protein content by the method of Bradford (1976)]. Xylan fermentation by strain $\mathrm{XB1A}^{\mathrm{T}}$ was further studied in 4-day cultures. Gases in the headspace of cultures were analysed by gas-phase chromatography (Chassard et al., 2005). Short-chain fatty acids in culture supernatants were quantified by ${ }^{1} \mathrm{D}^{1} \mathrm{H}$ NMR (Matulova et al., 2005). The xylanase activity of strain $\mathrm{XB1}^{\mathrm{T}}$ was determined by enzyme assays in which reducing sugars released from xylan oat spelts were measured colorimetrically (Forano et al., 1994).

Strain $\mathrm{XB1A}^{\mathrm{T}}$ was able to degrade xylan from different botanical origins (oat spelts and birchwood), as also described for B. ovatus (Cooper et al., 1985). Whereas most of the Bacteroides species, including B. ovatus and $B$. thetaiotaomicron, isolated from the human gut are able to ferment starch (Salyers et al., 1977), one of the main components of dietary fibre, strain $\mathrm{XB}^{\mathrm{T}} \mathrm{A}^{\mathrm{T}}$ did not exhibit the ability to degrade this substrate (Table 1). Strain XB1A ${ }^{\mathrm{T}}$ was also unable to use cellulose as an energy source and did not show cellulase activity. In 2-day-old xylan-grown cultures of strain $\mathrm{XB}^{\mathrm{T}} \mathrm{A}^{\mathrm{T}}$, high xylanase activities $\left[14.1 \pm 1.6 \mu \mathrm{g}\right.$ xylose $\left(\mathrm{mg}\right.$ protein $\left.\left.{ }^{-1}\right)\right]$ were measured that are similar to those reported for B. ovatus (Weaver et al., 1992), and further demonstrate the great xylanolytic potential of the new isolate. The end-products of xylan or xylose fermentation by strain $\mathrm{XB1A}^{\mathrm{T}}$ were mainly acetate, propionate and succinate; small amounts of $\mathrm{H}_{2}$ were also produced. Similarly, the majority of Bacteroides species from the human gut reportedly produce acetate, propionate and succinate from sugar fermentation as main end-products (Moore \& Holdeman, 1974; Salyers et al., 1981).

On the basis of these phenotypic, genotypic and phylogenetic differences from recognized species, we propose that strain $\mathrm{XB}^{\mathrm{A}} \mathrm{A}^{\mathrm{T}}$ represents a novel species of the genus Bacteroides. Strain $\mathrm{XB}_{1 \mathrm{~A}^{\mathrm{T}}}$ showed properties typical for the genus Bacteroides: Gram-negative, non-spore-forming, non-motile rods; obligately anaerobic growth; DNA $\mathrm{G}+\mathrm{C}$ content in the range $40-48 \mathrm{~mol} \%$ (Shah, 1992); saccharolytic, producing acetate and succinate as the major metabolic end-products (Holdeman \& Moore, 1974); and anteiso- $\mathrm{C}_{15: 0}$ as the major cellular fatty acid (Miyagawa et al., 1979). The closest recognized relative of strain $\mathrm{XB}_{1 \mathrm{~A}^{\mathrm{T}}}$ was $B$. ovatus, which was isolated from the human colon, but these two taxa showed a low level of DNA-DNA relatedness $\left(<70 \%\right.$ between strain $\mathrm{XB}^{\mathrm{T}} \mathrm{A}^{\mathrm{T}}$ and $B$. ovatus DSM $1896^{\mathrm{T}}$ ). Strain $\mathrm{XB1A}^{\mathrm{T}}$ and $B$. ovatus are able to degrade xylan but they showed important differences in their phenotypic characteristics, such as the expression of catalase, ability to degrade starch and ability to ferment glycerol, melezitose and D-sorbitol. The name Bacteroides xylanisolvens sp. nov. is proposed to accommodate the novel strains described herein.

\section{Description of Bacteroides xylanisolvens sp. nov.}

Bacteroides xylanisolvens (xy.lan.i.sol'vens. N.L. n. xylanum xylan, a vegetal polymer; L. part. adj. solvens dissolving; N.L. part. adj. xylanisolvens xylan-dissolving, referring to the ability of the micro-organism to degrade xylan).

Cells are non-motile rods, $1.8-2.5 \mu \mathrm{m}$ long and $0.2-0.3 \mu \mathrm{m}$ wide. Gram-negative by staining and cell-wall ultrastructure. 
No heat-resistant endospores are formed. Strictly anaerobic. Cytochrome oxidase- and catalase-negative. Metabolizes xylan to acetate, propionate and succinate. Poor growth is exhibited with arabinoxylan, pectin and galacturonic acid. No growth occurs with starch or cellulose. Growth occurs between 25 and $42{ }^{\circ} \mathrm{C}$ and at $\mathrm{pH}$ 6.0-7.2. Optimal growth conditions are $38{ }^{\circ} \mathrm{C}$ and $\mathrm{pH}$ 6.8. Rumen fluid is not required for growth. Indole-negative but able to hydrolyse aesculin. Nitrate is not reduced. No activity is detected for urease, and gelatin is not hydrolysed. Acid is produced from glucose, mannitol, lactose, sucrose, maltose, salicin, xylose, arabinose, glycerol, cellobiose, mannose, melezitose, raffinose, sorbitol, rhamnose and trehalose. Also able to ferment fructose, ribose, galactose and melibiose. Positive reactions are obtained (API Rapid ID 32A) for $\alpha$-galactosidase, $\beta$ galactosidase, $\alpha$-glucosidase, $\beta$-glucosidase, $\alpha$-arabinosidase, $N$-acetyl- $\beta$-glucosamidase, glutamic acid decarboxylase, $\alpha$ fucosidase, alkaline phosphatase, leucyl glycine arylamidase, alanine arylamidase and glutamyl glutamic acid arylamidase. Negative reactions are obtained for arginine dihydrolase, 6phospho- $\beta$-galactosidase, $\beta$-glucuronidase, arginine arylamidase, proline arylamidase, phenylalanine arylamidase, leucine arylamidase, pyroglutamic acid arylamidase, tyrosine arylamidase, glycine arylamidase, histidine arylamidase and serine arylamidase. The major fatty acids are anteiso$\mathrm{C}_{15: 0}(33.8 \%)$, iso- $\mathrm{C}_{17: 0} 3-\mathrm{OH}(23.5 \%)$ and iso- $\mathrm{C}_{15: 0}$ $(10.3 \%)$. The DNA $\mathrm{G}+\mathrm{C}$ content of the type strain is $42.8 \mathrm{~mol} \%$.

The type strain, XB1A ${ }^{\mathrm{T}}\left(=\mathrm{DSM} 18836^{\mathrm{T}}=\right.$ CCUG $\left.53782^{\mathrm{T}}\right)$, was isolated from human faeces of a non-methaneexcreting individual. Strains XB4A, XB3A, XB2A2, $\mathrm{XB} 41 \mathrm{~A}$ and $\mathrm{XO} 85 \mathrm{C} 13$, isolated from similar sources, are also included in the species.

\section{Acknowledgements}

C. C. was supported by a fellowship from the French Ministère de la Recherche et de l'Enseignement Supérieur. We express our thanks to V. Goumy and A. Ameilbone for technical assistance.

\section{References}

Bakir, M. A., Kitahara, M., Sakamoto, M., Matsumoto, M. \& Benno, Y. (2006). Bacteroides finegoldii sp. nov., isolated from human faeces. Int J Syst Evol Microbiol 56, 931-935.

Bayliss, C. E. \& Houston, A. P. (1984). Characterization of plant polysaccharide- and mucin-fermenting anaerobic bacteria from human feces. Appl Environ Microbiol 48, 626-632.

Bernalier, A., Willems, A., Leclerc, M., Rochet, V. \& Collins, M. D. (1996). Ruminococcus hydrogenotrophicus sp. nov., a new $\mathrm{H}_{2} / \mathrm{CO}_{2}$ utilizing acetogenic bacterium isolated from human feces. Arch Microbiol 166, 176-183.

Bradford, M. M. (1976). A rapid and sensitive method for the quantitation of microgram quantities of protein utilizing the principle of protein-dye binding. Anal Biochem 72, 248-254.

Cashion, P., Holder-Franklin, M. A., McCully, J. \& Franklin, M. (1977). A rapid method for the base ratio determination of bacterial DNA. Anal Biochem 81, 461-466.
Chassard, C., Gaillard-Martinie, B. \& Bernalier-Donadille, A. (2005). Interaction between $\mathrm{H}_{2}$-producing and non- $\mathrm{H}_{2}$-producing cellulolytic bacteria from the human colon. FEMS Microbiol Lett 242, 339-344.

Chassard, C., Goumy, V., Leclerc, M., Del'Homme, C. \& BernalierDonadille, A. (2007). Characterization of the xylan-degrading microbial community from human faeces. FEMS Microbiol Ecol 61, 121-131.

Cooper, S. W., Pfeiffer, D. G. \& Tally, F. P. (1985). Evaluation of xylan fermentation for the identification of Bacteroides ovatus and Bacteroides thetaiotaomicron. J Clin Microbiol 22, 125-126.

De Ley, J., Cattoir, H. \& Reynaerts, A. (1970). The quantitative measurement of DNA hybridization from renaturation rates. Eur $J$ Biochem 12, 133-142.

Forano, E., Brousolle, V., Gaudet, G. \& Bryant, J. A. (1994). Molecular cloning, expression and characterization of a new endoglucanase gene from Fibrobacter succinogenes S85. Curr Microbiol 28, 7-14.

Hespell, R. B. \& Whitehead, T. R. (1990). Physiology and genetics of xylan degradation by gastrointestinal tract bacteria. J Dairy Sci 73, 3013-3022.

Holdeman, L. V. \& Moore, W. E. C. (1974). Gram-negative anaerobic bacteria. In Bergey's Manual of Determinative Bacteriology, 8th edn, pp. 384-385. Edited by R. E. Buchanan \& N. E. Gibbons. Baltimore: Williams \& Wilkins.

Hungate, R. E. (1969). A roll tube method for cultivation of strict anaerobes. Methods Microbiol 3B, 117-132.

Huß, V. A. R., Festl, H. \& Schleifer, K. H. (1983). Studies on the spectrophotometric determination of DNA hybridization from renaturation rates. Syst Appl Microbiol 4, 184-192.

Matulova, M., Nouaille, R., Capek, P., Péan, M., Forano, E. \& Delort, A. M. (2005). Degradation of wheat straw by Fibrobacter succinogenes S85: a liquid and solid NMR study. Appl Environ Microbiol 71, 1247-1253.

Miyagawa, E., Azuma, R. \& Suto, T. (1979). Cellular fatty acid composition in Gram-negative obligately anaerobic rods. J Gen Appl Microbiol 25, 41-51.

Moore, W. E. C. \& Holdeman, L. V. (1974). Gram-negative anaerobic bacteria. In Bergey's Manual of Determinative Bacteriology, 8th edn, pp. 384-385. Edited by R. E. Buchanan \& N. E. Gibbons. Baltimore: Williams \& Wilkins.

Nicholas, K. B., Nicholas, H. B., Jr \& Deerfield, D. W., II (1997). GeneDoc: analysis and visualization of genetic variation. EMBnet News 4 2, 1-4. http://www.embnet.org/download/embnetnews/ embnet_news_4_2.pdf

Page, R. D. M. (1996). TreeView: an application to display phylogenetic trees on personal computers. Comput Appl Biosci 12, 357-358.

Pearson, W. R. \& Lipman, D. J. (1985). Rapid and sensitive protein similarity searches. Science 227, 1435-1441.

Rasmussen, S. W. (2002). SEQtools, a software package for analysis of nucleotide and protein sequences. http://www.seqtools.dk

Robert, C. \& Bernalier-Donadille, A. (2003). The cellulolytic microflora of the human colon: evidence of microcrystalline cellulose-degrading bacteria in methane-excreting subjects. FEMS Microbiol Ecol 46, 81-89.

Robert, C., Chassard, C., Lawson, P. A. \& Bernalier-Donadille, A. (2007). Bacteroides cellulosilyticus sp. nov., a cellulolytic bacterium from the human colon. Int J Syst Evol Microbiol 57, 1516-1520.

Saitou, N. \& Nei, M. (1987). The neighbor-joining method: a new method for reconstructing phylogenetic trees. Mol Biol Evol 4, 406-425.

Salyers, A. A. (1995). Fermentation of polysaccharides by human colonic anaerobes. In Dietary Fibre, pp. 29-35. Edited by 
C. Cherbut, J. L. Barry, D. Lairon \& M. Durand. Paris: John Libbey Eurotext.

Salyers, A. A., Vercellotti, J. R., West, S. \& Wilkins, T. D. (1977), Fermentation of mucin and plant polysaccharides by strains of Bacteroides from the human colon. Appl Environ Microbiol 33, 319-322.

Salyers, A. A., Gherardini, F. \& O'Brien, M. (1981). Utilization of xylan by two species of human colonic Bacteroides. Appl Environ Microbiol 41, 1065-1068.

Shah, H. N. (1992). The genus Bacteroides and related taxa. In The Prokaryotes, 2nd edn, pp. 3593-3607. Edited by A. Balows, H. G. Trüper, M. Dworkin, W. Harder \& K. Schleifer. New York: Springer.

Slavin, J. L., Brauer, P. M. \& Marlett, J. A. (1981). Neutral detergent fiber, hemicellulose and cellulose digestibility in human subjects. J Nutr 111, 287-297.
Stackebrandt, E. \& Ebers, J. (2006). Taxonomic parameters revisited: tarnished gold standards. Microbiol Today 33, 152-155.

Stackebrandt, E. \& Goebel, B. M. (1994). Taxonomic note: a place for DNA-DNA reassociation and $16 \mathrm{~S}$ rRNA sequence analysis in the present species definition in bacteriology. Int J Syst Bacteriol 44, 846-849.

Weaver, J., Whitehead, T. R., Cotta, M. A., Valentine, P. C. \& Salyers, A. A. (1992). Genetic analysis of a locus on the Bacteroides ovatus chromosome which contains xylan utilization genes. Appl Environ Microbiol 58, 2764-2770.

Wedekind, K. J., Mansfield, H. R. \& Mongomery, Y. L. (1988). Enumeration and isolation of cellulolytic and hemicellulolytic bacteria from human feces. Appl Environ Microbiol 54, 1530-1535. 